\title{
Surface Wettability Controllable Polyimides Bearing Long- chain Alkyl Groups by UV Light Irradiation
}

\author{
Yusuke Tsuda* and Syouma Kawabata \\ Department of Biochemistry \& Applied Chemistry \\ Kurume National College of Technology, \\ Komorino 1-1-1, Kurume, Fukuoka 830-8555, Japan \\ *tsuda@kurume-nct.ac.jp
}

\begin{abstract}
The novel aromatic diamine monomer, 4-(3,5-diaminobenzoyl)phenyl 3,4,5tris(decyloxy)benzoate ( $3 \mathrm{C}_{10}$-PEBPDA) having three long-chain alkyl groups connected by phenylester and benzophenone linkages was synthesized via six step reactions from gallic acid methyl ester. The novel polyimides and copolyimides were synthesized from 3,4'-oxydiphthalic anhydride (3,4'-ODPA) as a dianhydride, $3 \mathrm{C}_{10}$-PEBPDA, and 4,4'diaminodiphenylether (DDE) as a diamine co-monomer by two step polymerization systems. The thin films of obtained polyimides were irradiated by UV light $(\lambda \max ; 254$ $\mathrm{nm}$ ), and the contact angles for the water decreased from near $100^{\circ}$ (hydrophobicity) to near $50^{\circ}$ (hydrophilicity) in proportion to irradiated UV light energy. Furthermore, it was observed that the incorporation ratios of $3 \mathrm{C}_{10}$-PEBPDA in copolyimides affected the changes of surface wettability by UV light irradiation. From the result of various analytical experiments, it is recognized that the hydrophobic long-chain alkyl groups on the polyimide surface decrease and the hydrophilic groups such as hydroxyl groups and carboxyl groups generate on their surface, and that oxygen in an air affect the generation of these hydrophilic groups.
\end{abstract}

Keywords: Polyimide, Long-chain alkyl group, UV light irradiation, Surface wettability, Printed electronics

\section{Introduction}

Polyimides exhibit excellent thermal and mechanical properties, and have extensive engineering and microelectronics applications $[1,2]$. Recently, the printed electronics technology, by which the conductive lines (circuit) can be printed onto the plastic substrate, has been investigated. Polyimide films are the most promising plastics for use in printed electronics because of their high thermal stability. Various approaches such as the use of repellent pore-structured polyimide films [3], the surface energy controlled ink-jet printing with UV irradiation [4], have been investigated to obtain the fine patterning.

The authors also have investigated the surface wettability control of polyimides bearing long-chain alkyl groups by UV light irradiation [5-15]. The incorporation of longchain alkyl groups in polyimide backbones has been performed by using the various diamine monomers having long-chain alkyl groups. From the results of various analytical experiments, it is recognized that the hydrophobic groups such as long-chain alkyl groups on the polyimide surface are cleaved or oxidized and the hydrophilic groups such as carboxyl groups and hydroxyl groups generate on their surface by UV light irradiation. The library of these diamine monomers contains 4-[3,5-Bis(3-aminophenyl)phenyl] carbonylamino]phenyl 3,4,5-tris(n-dodecyloxy)benzyloxy benzoate (12G1-AGTerphenyldiamine) [5], 4-[3,5-Bis(3aminophenyl)benzophenone]phenyl 3,4,5tris(decyloxy)benzoate (TerKetone) [7], 4- 
(3,5-diaminophenyl carboxy) phenyl 3,4,5tris(decyloxy) benzoate $\left(3 \mathrm{C}_{10}\right.$-PEPEDA; phenyl ester phenyl ester diamine) and 4-(3,5diaminophenyl carboxy) phenyl 3,4,5tris(dodecyloxy) benzoate $\left(3 \mathrm{C}_{12}\right.$-PEPEDA; phenyl ester phenyl ester diamine) [6,9], 4(3,5-diaminobenzamide)phenyl 3,4,5tris(decyloxy)benzoate $\quad\left(3 \mathrm{C}_{10}\right.$-PEPADA; phenyl ester phenyl amide diamine) [6,9], and $3,4,5$-tris(decyloxy)- $N$-(4-(3,5-diamino benzamide) phenyl)benzamide ( $3 \mathrm{C}_{10}$-PAPADA; phenyl amide phenyl amide diamine) [6] (Fig. 1).

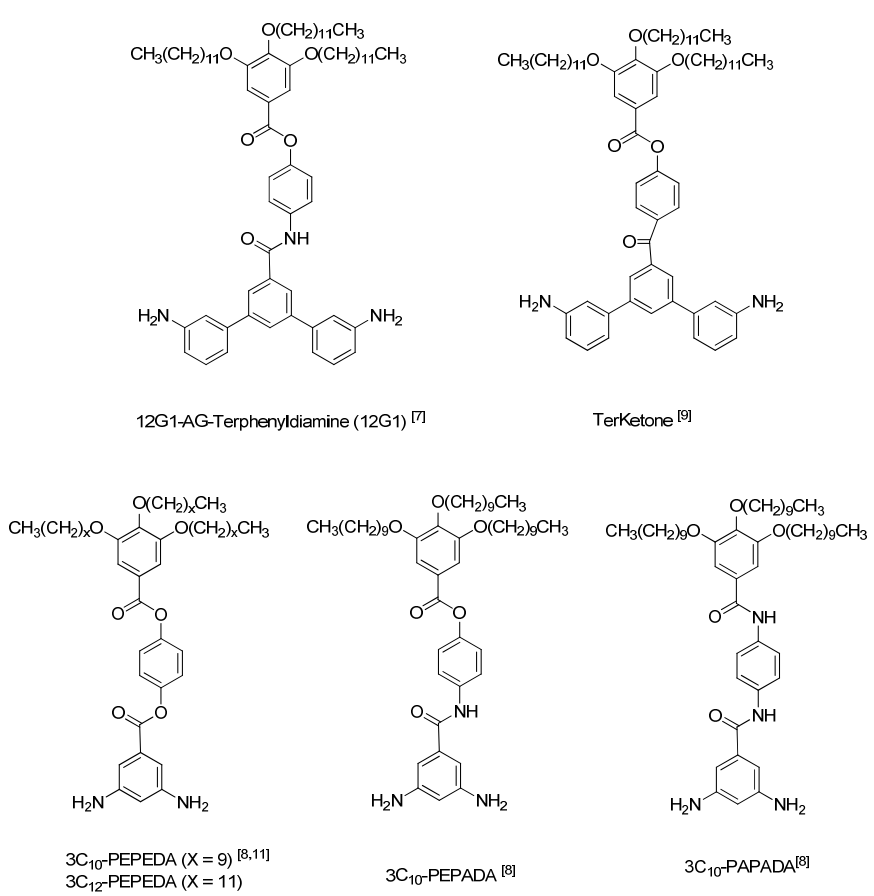

Fig. 1. Diamine monomers having long-chain alkyl groups previously reported.

In this paper, we report the synthesis and properties of the novel polyimides and copolyimides having long-chain alkyl groups based on a novel diamine monomer, 4-(3,5diaminobenzoyl)phenyl 3,4,5-tris(decyloxy) benzoate $\left(3 \mathrm{C}_{10}\right.$-PEBPDA; $3 \mathrm{C}_{10}$-phenylester benzophenone diamine) having three decyl groups $\left(3 \mathrm{C}_{10}\right)$ connected by phenylester and benzophenone linkages synthesized via several step reactions from gallic acid methyl ester. The characteristic feature of $3 \mathrm{C}_{10}$-PEBPDA is that this diamine monomer contains both phenyl ester and benzophenone linkages. According to our previous researches, the phenyl ester linkage group seem to enhance the wettability change by UV light irradiation [6,
9], and the benzophenone linkage seem to play a characteristic roll in the wettability change by UV light irradiation [7]. Although the similar researches have been reported from our laboratory, this paper features the detailed explanation of synthetic procedures and properties of the functional polyimides, also describes some analytical experimental results for explaining the mechanism of these surface wettability changes.

\section{Experimental}

\subsection{Materials}

3,4'-Oxydiphthalic anhydride (3,4'-ODPA; a-ODPA) from Shanghai Research Institute of Synthetic Resins was used after drying in a vacuum oven. Ultra-pure grade of N-methyl2-pyrrolidone (NMP) was purchased from Kanto Chemical Co., Inc. and used as received. Other reagents were purchased from TCI or Wako Pure Chemical Industries (Wako) and used as received.

\subsection{Synthesis of $3 \mathrm{C}_{10}$-PEBPDA}

$3 \mathrm{C}_{10}$-PEBPDA having three long-chain alkyl groups connected by phenylester and benzophenone linkages was synthesized via six step reactions from gallic acid methyl ester as a starting material (Fig. 2). 3,5-Dinitro-4hydroxybenzophenone (1) were synthesized from 3,5-dinitrobenzoyl chloride and anisole by Friedel-Crafts acylation reaction using aluminum chloride as a catalyst, followed by demethylation using hydrogen bromide as the same manner previously reported [16]. 3,4,5Tris(decyloxy) benzoic acid (2) were synthesized from gallic acid methyl ester followed by Williamson etherification reaction using decylbromide, then hydrolysis reaction in potassium hydroxide solution as the same manner described in previous literatures [17, 18].

Synthesis of 4-(3,5-dinitrobenzoyl)phenyl 3,4,5-tris(decyloxy)benzoate (3): 3,5-dinitro4'-methoxybenzophenone $(1,1.00 \mathrm{~g}, 3.47$ mmol) and 3,4,5-tris(decyloxy) benzoic acid $(2,2.03 \mathrm{~g}, 3.43 \mathrm{mmol})$ were dissolve in $65 \mathrm{ml}$ of dry dichloromethane. After adding $N, N$ dicyclohexylcarbodiimide (DCC, $1.43 \mathrm{~g}, 6.94$ mmol) and a catalytic amount of N,Ndimethyl-4-aminopyridine (DMAP) while stirring, the reaction was continued for $24 \mathrm{~h}$ at $50{ }^{\circ} \mathrm{C}$. Completion of the reaction was 
monitored by thin layer chromatography (TLC, MERCK Silica gel F254, dichloromethane, $\mathrm{R}_{\mathrm{f}}$ $=0.88)$. Precipitated $N, N$-dicyclohexylurea (DCU) was filtered off, and the filtrate was evaporated and the residue was subjected to a column chromatograph (Wako $\mathrm{SiO}_{2} \mathrm{C}-300$, $\mathrm{CH}_{2} \mathrm{Cl}_{2}$ ). The first fraction was collected and evaporated, then, the residue was washed with hot methanol. Yield, 89\%. Mp $56.0{ }^{\circ} \mathrm{C} ;{ }^{1} \mathrm{H}$ NMR (400 MHz, $\left.\mathrm{CDCl}_{3}, \delta \mathrm{ppm}\right): 0.86-0.90$ (t, $\left.9 \mathrm{H},-\mathrm{OCH}_{2} \mathrm{CH}_{2} \mathrm{CH}_{2}\left(\mathrm{CH}_{2}\right)_{6} \mathrm{CH}_{3}\right), 1.27-1.37$ (m, $\left.36 \mathrm{H},-\mathrm{OCH}_{2} \mathrm{CH}_{2} \mathrm{CH}_{2}\left(\mathrm{CH}_{2}\right)_{6} \mathrm{CH}_{3}\right), 1.46-1.51(\mathrm{~m}$, $\left.6 \mathrm{H},-\mathrm{OCH}_{2} \mathrm{CH}_{2} \mathrm{CH}_{2}\left(\mathrm{CH}_{2}\right)_{6} \mathrm{CH}_{3}\right), 1.73-1.88$ (m, $\left.6 \mathrm{H},-\mathrm{OCH}_{2} \mathrm{CH}_{2} \mathrm{CH}_{2}\left(\mathrm{CH}_{2}\right)_{6} \mathrm{CH}_{3}\right)$, 4.04-4.09 (m, $\left.6 \mathrm{H},-\mathrm{OCH}_{2} \mathrm{CH}_{2} \mathrm{CH}_{2}\left(\mathrm{CH}_{2}\right)_{6} \mathrm{CH}_{3}\right), 7.41(\mathrm{~s}, 2 \mathrm{H}$, $\mathrm{Ha}), 7.45(\mathrm{~d}, 2 \mathrm{H}, \mathrm{Hb}, \mathrm{J}=8.7 \mathrm{~Hz}), 7.93(\mathrm{~d}, 2 \mathrm{H}$, $\mathrm{Hc}, \mathrm{J}=8.8 \mathrm{~Hz}), 8.96(\mathrm{~d}, 2 \mathrm{H}, \mathrm{Hd}, J=2.0 \mathrm{~Hz})$, 9.27 (t, 1H, He, $J=2.0 \mathrm{~Hz}$ ) ppm (Fig. 4); IR (ATR): 2920 and $2850(\mathrm{C}-\mathrm{H}), 1730$ and 1670 $(\mathrm{C}=\mathrm{O}), 1540$ and $1340\left(\mathrm{NO}_{2}\right), 1190(-\mathrm{O}-) \mathrm{cm}^{-1}$. Anal. Calcd for $\mathrm{C}_{50} \mathrm{H}_{72} \mathrm{~N}_{2} \mathrm{O}_{10}: \mathrm{C}, 69.74 \% ; \mathrm{H}$, $8.43 \%$; N, 3.25\%. Found: C, $69.50 \%$; $\mathrm{H}$, $8.48 \% ; \mathrm{N}, 3.02 \%$.
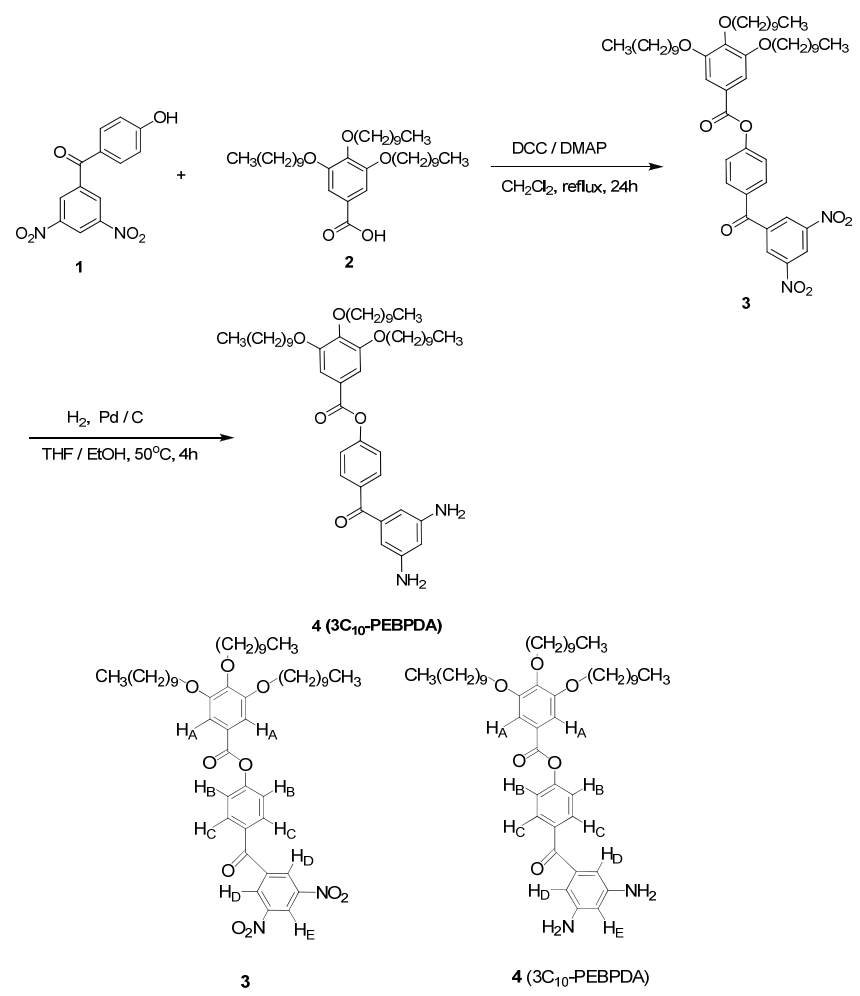

Fig. 2. Synthesis of $3 \mathrm{C}_{10}$-PEBPDA.

Synthesis of 4-(3,5-diaminobenzoyl)phenyl 3,4,5-tris(decyloxy)benzoate $\quad\left(4, \quad 3 \mathrm{C}_{10^{-}}\right.$ PEBPDA): a mixture of 4-(3,5-dinitrobenzoyl) phenyl 3,4,5-tris(decyloxy)benzoate $(3,1.00 \mathrm{~g}$, $1.16 \mathrm{mmol}$ ) and $10 \%$ palladium on carbon $(\mathrm{Pd} / \mathrm{C}, 0.12 \mathrm{~g})$ in a mixture of tetrahydrofuran
(THF; $5 \mathrm{~mL}$ ) and ethanol $(20 \mathrm{~mL})$ was stirred at $50{ }^{\circ} \mathrm{C}$ for $4 \mathrm{~h}$ using the apparatus attached with a balloon filled with hydrogen gas. Completion of the reaction was monitored by thin layer chromatography (TLC, MERCK Silica gel F254, ethyl acetate / hexane $=1: 1$, $\left.\mathrm{R}_{\mathrm{f}}=0.58\right)$. The $\mathrm{Pd} / \mathrm{C}$ was filtered off and the solvent were evaporated. The residue was subjected to a column chromatograph (Wako $\mathrm{SiO}_{2} \mathrm{C}-300$, ethyl acetate/ hexane $\left.=1: 1\right)$. The second fraction was collected and recrystallized from methanol. Yield, $22 \%$. Mp $77.0{ }^{\circ} \mathrm{C} ;{ }^{1} \mathrm{H}$ NMR $\left(400 \mathrm{MHz}, \mathrm{CDCl}_{3}, \delta \mathrm{ppm}\right)$ : 0.86-0.90 (m, 9H, $\left.-\mathrm{OCH}_{2} \mathrm{CH}_{2} \mathrm{CH}_{2}\left(\mathrm{CH}_{2}\right)_{6} \mathrm{CH}_{3}\right)$, 1.27-1.34 (m, $\left.36 \mathrm{H},-\mathrm{OCH}_{2} \mathrm{CH}_{2} \mathrm{CH}_{2}\left(\mathrm{CH}_{2}\right)_{6} \mathrm{CH}_{3}\right)$, 1.45-1.53 (m, $\left.6 \mathrm{H},-\mathrm{OCH}_{2} \mathrm{CH}_{2} \mathrm{CH}_{2}\left(\mathrm{CH}_{2}\right)_{6} \mathrm{CH}_{3}\right)$, 1.73-1.87 (m, 6H, - $\left.\mathrm{OCH}_{2} \mathrm{CH}_{2} \mathrm{CH}_{2}\left(\mathrm{CH}_{2}\right)_{6} \mathrm{CH}_{3}\right)$, 3.72 (broad s, 4H, - $\left.\mathrm{NH}_{2}\right)$, 4.04-4.09 (m, 6H, $\left.\mathrm{OCH}_{2} \mathrm{CH}_{2} \mathrm{CH}_{2}\left(\mathrm{CH}_{2}\right)_{6} \mathrm{CH}_{3}\right), 6.23(\mathrm{t}, 1 \mathrm{H}, \mathrm{Ha}, J=$ $2.0 \mathrm{~Hz}), 6.51(\mathrm{~d}, 2 \mathrm{H}, \mathrm{Hb}, J=2.0 \mathrm{~Hz}), 7.29(\mathrm{~d}$, $2 \mathrm{H}, \mathrm{Hc}, J=8.5 \mathrm{~Hz}), 7.41$ (s, 2H, Hd), $7.91(\mathrm{~d}$, $2 \mathrm{H}, \mathrm{He}, J=8.5 \mathrm{~Hz}$ ) ppm (Fig. 4); IR (ATR): $3380\left(\mathrm{NH}_{2}\right), 2920$ and $2850(\mathrm{C}-\mathrm{H}), 1730$ and $1660(\mathrm{C}=\mathrm{O}), 1190(-\mathrm{O}-) \mathrm{cm}^{-1}$. Anal. Calcd for $\mathrm{C}_{50} \mathrm{H}_{76} \mathrm{~N}_{2} \mathrm{O}_{6}$ : C, 74.96\%; H, 9.56\%; N, 3.50\%. Found: C, 74.66\%; H, 9.46\%; N, 3.47\%.

\subsection{Synthesis of Polyimides Having $3 \mathrm{C}_{10^{-}}$ PEBPDA}

Two step polymerization systems including poly(amic acid)s synthesis and chemical imidization were performed (Fig. 3). The poly(amic acid)s were obtained by reacting the mixture of diamines with an equimolar amount of 3,4'-ODPA at room temperature for $12 \mathrm{~h}$ under a nitrogen atmosphere. The polyimides were obtained by chemical imidization at $120^{\circ} \mathrm{C}$ in the presence of pyridine as a base catalyst and acetic anhydride as a dehydrating reagent. The experimental details are described in the previous papers [5-15].

\subsection{Measurements}

${ }^{1} \mathrm{H}$ NMR spectra were measured on a JEOL JNM-AL400 FT NMR in $\mathrm{CDCl}_{3}$ or dimethyl sulfoxide- $\mathrm{d}_{6}$ with tetramethylsilane (TMS) as an internal reference. Size exclusion chromatography (SEC) measurements were performed in NMP containing $10 \mathrm{mM} \mathrm{LiBr}$ at $40{ }^{\circ} \mathrm{C}$ with a TOSOH HLC-8020 equipped with a TSK-GEL ALPHA-M. Number average molecular weights $(M n)$, weight average 


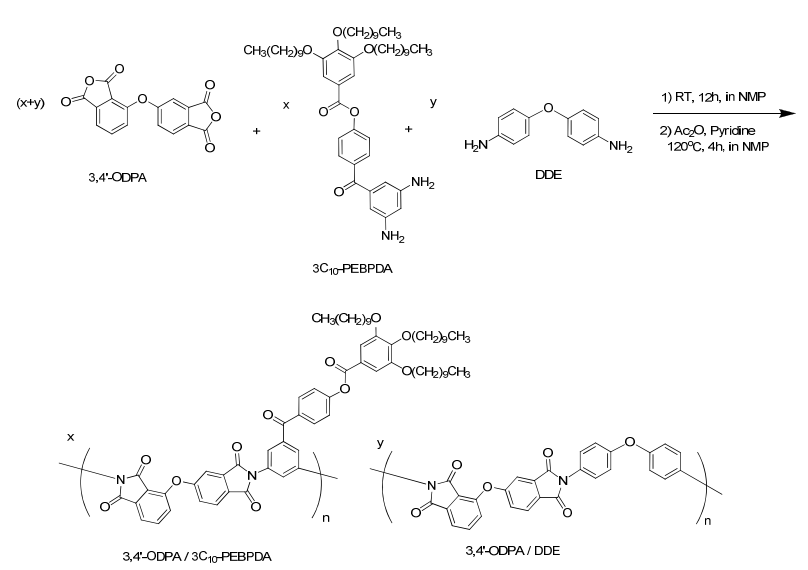

Fig. 3. Chemical structures of polyimides based on 3,4 '-ODPA $/ 3 \mathrm{C}_{10}$-PEBPDA and DSDA/3C $10^{-}$ PEBPDA.

molecular weights $(M w)$, and polydispersities $(M w / M n)$ were determined by TOSOH Multi Station GPC-8020 calibrated with a series of polystyrenes as a standard. Thermogravimetric analysis (TGA) was performed on a Shimadzu TGA-50 in air or under nitrogen $(50 \mathrm{~mL} / \mathrm{min})$ at a heating rate of $10{ }^{\circ} \mathrm{C} / \mathrm{min}$ using ca. $5 \mathrm{mg}$ of a dry powder sample, and initial decomposition temperatures $\left(T \mathrm{~d}_{0}\right), 5 \%$ weight loss temperatures $\left(T \mathrm{~d}_{5}\right)$, and $10 \%$ weight loss temperatures $\left(T \mathrm{~d}_{10}\right)$ were calculated from the second heating scan after cooling from $250{ }^{\circ} \mathrm{C}$ to $800{ }^{\circ} \mathrm{C}$. Differential scanning calorimeter (DSC) traces were measured on a Shimadzu DSC-60 under nitrogen at a heating rate of 10 ${ }^{\circ} \mathrm{C} / \mathrm{min}$ and glass transition temperatures $(\mathrm{Tg})$ were read at the midpoint of the heat capacity jump from the second heating scan. Polyimide thin-films were obtained as follows: 1.0-5.0 $\mathrm{wt} \%$ polyimide solution in NMP were cast on glass substrates and the solution were slowly evaporated by heating at approximately 100-120 ${ }^{\circ} \mathrm{C}$ until the films were dried, then the films were dried in a vacuum oven at $100{ }^{\circ} \mathrm{C}$ for $12 \mathrm{~h}$. Water contact angles were measured by SImage mini (Excimer. Inc., Japan) and UV light irradiation were performed using UV lamp unit E50-254-270U$1\left(\lambda \max ; 254 \mathrm{~nm}, 6.0 \mathrm{~mW} / \mathrm{cm}^{2}\right.$, Excimer. Inc., Japan) and a cool plate NCP-2215 (NISSIN Laboratory equipment, Japan) adjusted at 25 ${ }^{\circ} \mathrm{C}$ that was used to avoid the effect of the heat that arose in UV light irradiation process. IR (ATR) measurements were performed by JASCO FT/IR-470 with ATR PRO450-S (Ge prism). XPS measurements were carried out on an XPS-APEX (Physical Electronics Co. Ltd.) with an $\mathrm{Al} \mathrm{K} \alpha \mathrm{X}$-ray source $(150 \mathrm{~W})$. Chamber pressure; $10^{-9}-10^{-10} \mathrm{~Pa}$; take off angles; $\quad 15^{\circ}, \quad 30^{\circ}, \quad 45^{\circ}$. SFM (SII Nanotechnology Inc., SPA 400) was operated in a dynamic force microscopic (DFM) mode.

\section{Results and discussion}

\subsection{Synthesis of $3 \mathrm{C}_{10}$-PEBPDA}

The synthetic strategy for $3 \mathrm{C}_{10}$-PEBPDA includes several key points as follows. As the building block containing long-chain alkyl groups, we select gallic acid substituted by long-chain alkyloxy groups that are expected to show the high hydrophobicity due to multiple long-chain alkyl groups. The alkyl chain length is fixed as decyl group $\left(\mathrm{C}_{10}\right)$, because it is concluded that decyl group is the effective chain length for the generation of hydrophobicity and the improvement of solubility of polyimides according to our previous research [19]. As the connecting group of gallic acid having long-chain alkyl groups and an aromatic diamine, we select the combination of phenyl ester (phenyl benzoate) group and benzophenone group. Because, phenyl ester (phenyl benzoate) group has the possibility to cause the photo reactions such as photo-Fries rearrangement and generate hydoxy groups, and benzophenone is the representative photosensitizer. The synthesis of $3 \mathrm{C}_{10}$-PEBPDA was performed by a condensation of two building blocks (compounds $\mathbf{1}$ and 2) using DCC/DMAP followed by a catalytic hydrogenation using $\mathrm{Pd} / \mathrm{C}$ (palladium on carbon). Although various hydrogenation catalysts such as $\mathrm{Os} / \mathrm{C}$ (osmium activated carbon) and $\mathrm{Pd} / \mathrm{Fib}$ (palladium-fibroin) and the various reaction conditions were tried, the yields of these experiments were as low as $22 \%$. The improvement on the yield will be desired in future.

3.2. Synthesis of polyimides and copolyimides based on $3 \mathrm{C}_{10}$-PEBPDA

The synthetic route of the polyimides and copolyimides based on $3 \mathrm{C}_{10}$-PEBPDA is illustrated in Fig. 3. Two step polymerization systems including poly(amic acid)s synthesis and chemical imidization were performed. These are the optimized synthetic conditions previously developed for 
the synthesis of soluble polyimides in our laboratory $[3-15,19,20]$. If the polyimides were insoluble in the polymerization solvent, NMP, gelation or precipitation happened in the course of imidization process. 3,4'-ODPA (a-ODPA; asymmetric ODPA) known as an aromatic tetracarboxylic dianhydride monomer suitable for soluble polyimides [21] was used. DDE, that is a high reactive and common aromatic diamine, was used as a diamine co-monomer.

Experimental results of the synthesis of polyimides and copolyimides based on $3 \mathrm{C}_{10^{-}}$ PEBPDA are summarized in Table 1. All of polyimides and copolyimides were soluble in polymerization solvent, NMP without any problem. As these polyimides were also soluble in $\mathrm{CHCl}_{3}$, the incorporation of $3 \mathrm{C}_{10^{-}}$ PEBPDA units in polymer backbones were directly observed by ${ }^{1} \mathrm{H}$ NMR measurements using $\mathrm{CDCl}_{3}$ as a NMR solvent (ca. $1 \mathrm{wt} \%$, NMR). These molecular weights of obtained polyimides were evaluated by means of SEC measurements (Table 1). The number average molecular weights $(M \mathrm{n})$ and weight average molecular weights $(M \mathrm{w})$ determined by SEC measurements were in the range of 4200 to $39100(\mathrm{Mn}), 6500$ to $75400(\mathrm{Mw})$ respectively. These values indicated that the molecular weights of these polyimides are considered medium or rather lower values for polyimides, however, all polyimides show the good film formation ability. The molecular weights were increased with the amounts of DDE that is a high reactive diamine in comparison with $3 \mathrm{C}_{10}$-PEBPDA that is a steric hindered and low reactive $m$-substituted diamine. The $\mathrm{Mn}$ and Mw of homopolyimide based on 3,4'ODPA $/ 3 C_{10}$-PEBPDA seem to be very low for the polymers having film forming ability. It can be imagined that the polymer structure became more spherical due to the attachment of multiple long chain alkyl groups, so apparent molecular weights observed by SEC measurements seem to decrease, as describing in our previous literature [7].

\subsection{Thermal properties of polyimides based} on $3 \mathrm{C}_{10}$-PEBPDA

The glass transition temperatures $(T \mathrm{~g})$ of these polyimides were determined by DSC measurements and the thermal stabilities were evaluated by $0 \mathrm{wt} \%$ weight-loss temperatures
Table 1. Polyimides and copolyimides based on $3 \mathrm{C}_{10}$-PEBPDA.

\begin{tabular}{|c|c|c|c|c|c|c|c|}
\hline \multicolumn{3}{|c|}{ Monomer } & \multicolumn{5}{|c|}{ Polyimide } \\
\hline \multirow[t]{2}{*}{ Dianhydride } & \multicolumn{2}{|c|}{ Diamine } & \multicolumn{2}{|c|}{ Solubility } & \multicolumn{3}{|c|}{ Molecular Weight ${ }^{\mathrm{a}}$} \\
\hline & $\mathrm{mol} \%$ & & NMP & $\mathrm{CHCl}_{3}$ & $\mathrm{Mn}$ & $\mathrm{Mw}$ & $\mathrm{Mw} / \mathrm{Mn}$ \\
\hline 3,4'-ODPA & $3 \mathrm{C}_{10}$-PEBPDA & DDE & & & & & \\
\hline 100 & 100 & 0 & soluble & soluble & 4200 & 6500 & 1.6 \\
\hline 100 & 75 & 25 & soluble & soluble & 5500 & 9800 & 1.8 \\
\hline 100 & 50 & 50 & soluble & soluble & 9600 & 21900 & 1.8 \\
\hline 100 & 25 & 75 & soluble & soluble & 18800 & 53500 & 2.8 \\
\hline 100 & 10 & 90 & soluble & soluble & 18400 & 49900 & 2.7 \\
\hline 100 & 0 & 100 & soluble & soluble & 39100 & 75400 & 1.9 \\
\hline
\end{tabular}

${ }^{a}$ Determined by SEC in NMP containing $10 \mathrm{mM} \mathrm{LiBr}$

calibrated with a series of polystyrene as a standard.

( $T \mathrm{~d}_{0}$, degradation onsets), $5 \mathrm{wt} \%$ weight-loss temperatures $\left(T \mathrm{~d}_{5}\right)$, and $10 \mathrm{wt} \%$ weight-loss temperatures $\left(T \mathrm{~d}_{10}\right)$ in TGA measurements. All data are summarized in Table 2. Tg values obtained by DSC were in the ranged from 193$200{ }^{\circ} \mathrm{C}$, meaning that the glass transition temperatures lower from $274{ }^{\circ} \mathrm{C}$ by the introduction of $3 \mathrm{C}_{10}$-PEBPDA. It is speculated that the flexible long-chain alkyl groups in $3 \mathrm{C}_{10}$-PEBPDA lower the glass transition temperatures. The thermal stabilities of obtained soluble polyimides were evaluated in air and under nitrogen atmospheres using $\mathrm{Td}_{0}$ (degradation onset), $T \mathrm{~d}_{5}$ and $T \mathrm{~d}_{10}$ for comparison. $T \mathrm{~d}_{0}$ of polyimides based on polyimides and copolyimides based on $3 \mathrm{C}_{10}$ PEBPDA were in the range of $312-382{ }^{\circ} \mathrm{C}$ in air and $346-407{ }^{\circ} \mathrm{C}$ under nitrogen, $T \mathrm{~d}_{5}$ of these polyimides were in the range of $387-437{ }^{\circ} \mathrm{C}$ in air and $394-448{ }^{\circ} \mathrm{C}$ under nitrogen, and $\mathrm{Td}_{10}$ of these polyimides were in the range of 403-536 ${ }^{\circ} \mathrm{C}$ in air and $409-531{ }^{\circ} \mathrm{C}$ under nitrogen. These values show the regular values that were observed in soluble polyimides based on longchain alkyl groups studied in our laboratory (ca. $350-500 \quad{ }^{\circ} \mathrm{C}$ ) $[3-7,19,20]$. As the incorporation of DDE resulted in a reduction of aliphatic components of the polyimides, $0 \%$, $5 \%$ and $10 \%$ weight-loss temperatures of these polyimides tended to increase by the increment of the DDE component. In most cases, Td values in air were lower than $\mathrm{Td}$ values under nitrogen following the general fact that oxidative degradation proceeds rapidly in air than under nitrogen. Consequently, above degradation temperatures are $100-200{ }^{\circ} \mathrm{C}$ lower than the conventional fully aromatic polyimides, however, obtained polyimides based on $3 \mathrm{C}_{10}$-PEBPDA still can be ranked as heat resistant polymers. 
Table 2. Thermal properties of polyimides and copolyimides based on $3 \mathrm{C}_{10}$-PEBPDA.

\begin{tabular}{|c|c|c|c|c|c|c|c|c|}
\hline \multicolumn{3}{|c|}{ Monomer } & \multicolumn{6}{|c|}{ Polyimide } \\
\hline Dianhydride & \multicolumn{2}{|c|}{ Diamine } & $\mathrm{Tg}^{\mathrm{a}}$ & \multicolumn{2}{|c|}{$\mathrm{Td}_{0}{ }^{\mathrm{b}}$} & $\mathrm{Td}_{5}{ }^{\mathrm{c}}$ & \multicolumn{2}{|c|}{$\operatorname{Td}_{10}{ }^{\mathrm{d}}$} \\
\hline \multirow{2}{*}{\multicolumn{3}{|c|}{$\mathrm{mol} \%$}} & \multirow{3}{*}{${ }^{\circ} \mathrm{C}$} & Air & $\mathrm{N}_{2}$ & Air & Air & $\mathrm{N}_{2}$ \\
\hline & & & & ${ }^{\circ} \mathrm{C}$ & ${ }^{\circ} \mathrm{C}$ & ${ }^{\circ} \mathrm{C}$ & ${ }^{\circ} \mathrm{C}$ & ${ }^{\circ} \mathrm{C}$ \\
\hline 3,4'-ODPA & $\begin{array}{c}3 \mathrm{C}_{10^{-}} \\
\text {PEBPDA }\end{array}$ & DDE & & & & & & \\
\hline 100 & 100 & 0 & 193 & 328 & 346 & 387 & 403 & 409 \\
\hline 100 & 75 & 25 & 196 & 312 & 368 & 393 & 418 & 420 \\
\hline 100 & 50 & 50 & 200 & 344 & 376 & 416 & 428 & 426 \\
\hline 100 & 25 & 75 & 199 & 338 & 367 & 383 & 426 & 441 \\
\hline 100 & 10 & 90 & 193 & 382 & 407 & 437 & 536 & 531 \\
\hline 100 & 0 & 100 & 274 & 557 & 554 & 581 & 595 & 596 \\
\hline
\end{tabular}

${ }^{a}$ Measured by DSC at a heating rate of $10{ }^{\circ} \mathrm{C} / \mathrm{min}$ in $\mathrm{N}_{2}$ on second heating. ${ }^{\mathrm{b}} 0 \%$ Weight loss temperature (degradation onset), measured by TGA at a heating rate of $10{ }^{\circ} \mathrm{C} / \mathrm{min} .{ }^{\mathrm{c}} 5 \%$ Weight loss temperature, measured by TGA at a heating rate of $10{ }^{\circ} \mathrm{C} / \mathrm{min} .{ }^{\mathrm{d}} 10 \%$ Weight loss temperature, measured by TGA at a heating rate of $10{ }^{\circ} \mathrm{C} / \mathrm{min}$.

3.4. Surface wettability control of polyimides based on $3 \mathrm{C}_{10}$-PEBPDA by UV light irradiation

The polyimide thin films were irradiated by UV light ( $\lambda \max ; 254 \mathrm{~nm}, 0,2,4,6,8 \mathrm{~J})$, then the contact angles for the water were measured. Fig. 4 shows UV light irradiation energy dependence of water contact angles of polyimide films based on $3 \mathrm{C}_{10}$-PEBPDA. The water contact angle of polyimide films based on 3,4'-ODPA/DDE polyimides before UV irradiation is $89.4 \mathrm{deg}$, while, those of $3,4^{\prime}$ ODPA/ $3 C_{10}$-PEBPDA/DDE copolyimides are around $100^{\circ}$. This high hydrophobicity is certainly due to the hydrophobic property of multiple long-chain alkyl groups. These high water contact angles of polyimides bearing long-chain alkyl groups decreased from around $100^{\circ}$ (hydrophobicity) to the minimum value; $50.9 \mathrm{deg}$ (hydrophilicity) in proportion to irradiated UV light energy. It is considered that these changes of surface wettability of polyimides are mainly based on the photodegradation or scission of long-chain alkyl groups and specific functional groups such as an ester group, and that the generation of the hydrophilic functional groups such as $\mathrm{COOH}$ and $\mathrm{OH}$ groups probably occurs. It is interesting that the changes of contact angles by UV light irradiation are larger in the case of copolyimides containing smaller amounts of $3 \mathrm{C}_{10}$-PEBPDA $\left(3 \mathrm{C}_{10}\right.$-PEBPDA; $25 \mathrm{~mol} \%, 10$ mol\%). On the other hand, the water contact angle of 3,4'-ODPA /DDE polyimide also somewhat decreases after UV light irradiation, therefore, the generation of hydrophilic groups on polymer main chains possibly occurs to some extent. Consequently, it can be imagined that the hydrophobicity is maintained by a large amounts of long-chain alkyl groups cover the top surface of polyimides, even if the hydrophilic groups are formed on the surface of polyimides by UV light irradiation, in the case that the concentration of the long-chain alkyl groups is larger $\left(3 \mathrm{C}_{10}\right.$-PEBPDA; 100 mol\%, $75 \mathrm{~mol} \%$, $50 \mathrm{~mol} \%$ ). The authors named this speculation as "the concentration effect" that was described in detail in the previous literature [7].

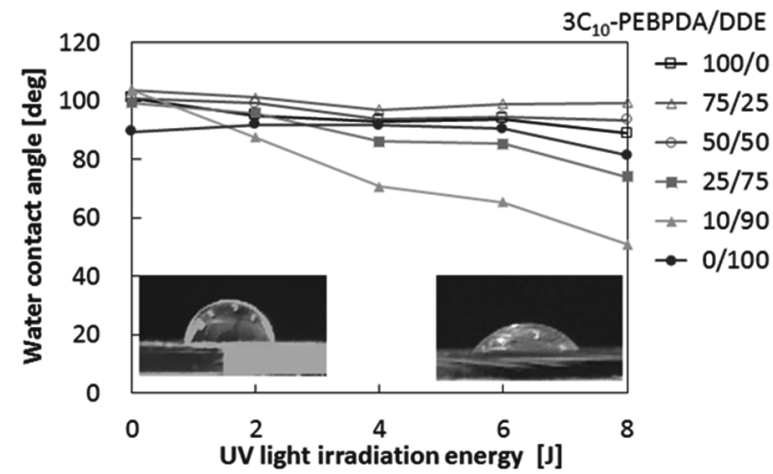

Fig. 4. UV light irradiation energy dependence of water contact angles of polyimide films.

\subsection{Surface analysis}

The surface analysis of the polyimide films were performed by ATR, XPS, and AFM. ATR measurements of the polyimide surface after UV light irradiation support the assumption that the generation of the hydrophilic functional groups such as $\mathrm{COOH}$ and $\mathrm{OH}$ groups occur. The absorption of $\mathrm{OH}$ groups around $3600 \mathrm{~cm}^{-1}$ appeared, the absorption of alkyl groups around $2900 \mathrm{~cm}^{-1}$ decreased, and the absorption of ether groups around $1200 \mathrm{~cm}^{-1}$ decreased by UV light irradiation (Fig. 5). In the case of ATR

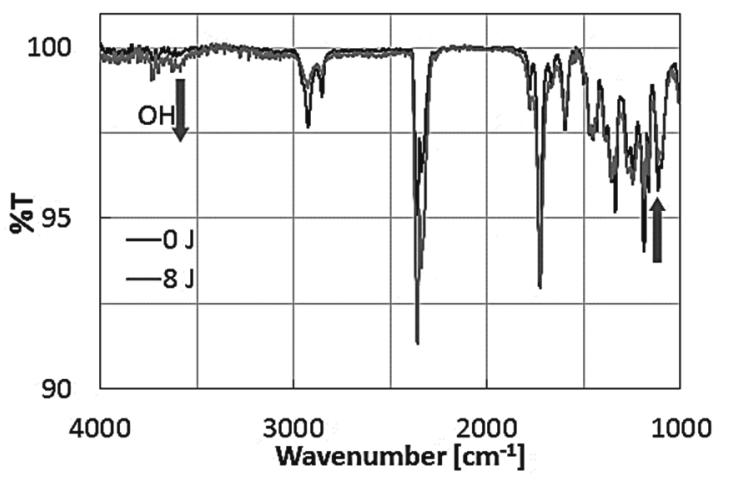

Fig. 5. ATR spectra of polyimide based on 3,4'ODPA/ $3 C_{10}$-PEBPDA (100/100) before and after UV light irradiation. ATR: attenuated total reflectance. 
measurements, the penetration depth of a beam of infrared light into the sample is typically between 0.5 and $2 \mu \mathrm{m}$. Therefore, the above ATR analysis does not reflect the chemical composition of the film top surface.

The intensive surface analyses were examined using XPS analysis that give the information of each elements at the region of the single nm depth from the film top surface before/after UV light irradiation. The atomic percent data of the polyimide surface based on the XPS measurements under the standard take-off angle (45 deg) are summarized in Table 3, using polyimide films containing different amounts of $3 \mathrm{C}_{10}$-PEBPDA (0 mol\%, $10 \mathrm{~mol} \%, 100 \mathrm{~mol} \%$ ). The observed atomic percent of $\mathrm{C}, \mathrm{O}, \mathrm{N}$ were calculated based on the peaks of $\mathrm{C}_{1 \mathrm{~s}}, \mathrm{O}_{1 \mathrm{~s}}$, and $\mathrm{N}_{1 \mathrm{~s}}$ respectively. In all cases, the atomic percent of $\mathrm{C}$ were decreased and the atomic percent of $\mathrm{O}$ were increased after UV light irradiation, meaning that $\mathrm{C}$ $\mathrm{C}$ bond based on alkyl groups decreased and $\mathrm{C}=\mathrm{O}$ and $\mathrm{C}-\mathrm{O}$ bond based on carboxyl groups and hydroxyl groups increased. However, these tendency was similar in both polyimides containing $3 \mathrm{C}_{10}$-PEBPDA $(10 \mathrm{~mol} \%, 100 \mathrm{~mol} \%)$ and it is difficult to explain why the lowering degree of the contact angle after UV light irradiation of the polyimide containing $10 \mathrm{~mol} \%$ of $3 \mathrm{C}_{10}$-PEBPDA is larger than those of the polyimide containing 100 mol $\%$ of $3 \mathrm{C}_{10}$-PEBPDA. In order to clarify this phenomena, the characterization of XPS narrow scans of $\mathrm{C}_{1 \mathrm{~s}}$ under the different take-off angles (4530-15 deg) were performed (Fig. 6). The information of the more top surface are obtained in the lower take-off angles (15 deg). Consequently, it was observed that the peaks based on $\mathrm{C}-\mathrm{O}$ and $\mathrm{C}=\mathrm{O}$ appears in the case of the polyimide containing $10 \mathrm{~mol} \%$ of $3 \mathrm{C}_{10}$-PEBPDA after UV light irradiation on the film top surface (take-off angle; $15 \mathrm{deg}$ ), while those peaks in the case of the polyimide containing $100 \mathrm{~mol} \%$ of $3 \mathrm{C}_{10}$-PEBPDA were not observed. On the other hand, it was observed $\mathrm{C}-\mathrm{O}$ and $\mathrm{C}=\mathrm{O}$ bonds at the deeper region from the top surface (the take-off angle; $30 \mathrm{deg}, 45$ deg) after UV light irradiation in the case of both polyimides containing $100 \mathrm{~mol} \%$ of $3 \mathrm{C}_{10}$-PEBPDA and containing $10 \mathrm{~mol} \%$ of $3 \mathrm{C}_{10}$-PEBPDA. It can be presumed that the larger amounts of long-chain alkyl groups of $3 \mathrm{C}_{10}$-PEBPDA cover the top surface of polyimide films after UV light irradiation, even though the carboxyl and hydroxyl groups partly generate.

The $\mathrm{nm}$ size micro roughnesses of film top surface was analyzed by AFM (DFM mode) (Fig. 7).
Table 3. Atomic percent of polyimide surface based on XPS measurements.

\begin{tabular}{|c|c|c|c|c|c|c|c|c|}
\hline \multirow{3}{*}{ Polyimide Sample } & \multicolumn{2}{|c|}{ Radiation Contact } & \multicolumn{6}{|c|}{ Atomic percent based on $\mathrm{XPS}^{\mathrm{c}}$} \\
\hline & \multirow{2}{*}{$\frac{\text { Energy }^{\mathrm{a}}}{(\mathrm{J})}$} & \multirow{2}{*}{$\frac{\text { Angle }^{\mathrm{b}}}{(\mathrm{deg})}$} & \multicolumn{2}{|c|}{ C (\%) } & \multicolumn{2}{|c|}{$\mathrm{O}(\%)$} & \multicolumn{2}{|c|}{$\mathrm{N}(\%)$} \\
\hline & & & Theo. & Obsd. & Theo. & Obsd. & Theo. & Obsd. \\
\hline \multirow{2}{*}{$\begin{array}{l}3,4^{\prime}-\mathrm{ODPA} / 3 \mathrm{C}_{10} \text {-PEBPDA / DDE } \\
(100 / 100 / 0)\end{array}$} & 0 & 100.8 & 79.5 & 77.8 & 17.7 & 18.4 & 2.8 & 3.8 \\
\hline & 8 & 88.9 & 79.5 & 68.7 & 17.7 & 27.8 & 2.8 & 3.5 \\
\hline \multirow{2}{*}{$\begin{array}{l}\text { 3,4'-ODPA / } 3 \mathrm{C}_{10} \text {-PEBPDA / DDE } \\
(100 / 10 / 90)\end{array}$} & 0 & 103.5 & 74.3 & 82.7 & 20.2 & 15.2 & 5.5 & 2.1 \\
\hline & 8 & 50.9 & 74.3 & 71 & 20.2 & 23.4 & 5.5 & 5.6 \\
\hline \multirow{2}{*}{$\begin{array}{l}\text { 3,4-ODPA / } 3 \mathrm{C}_{10} \text {-PEBPDA / DDE } \\
(100 / 0 / 100)\end{array}$} & 0 & 89.4 & 73.6 & 77.2 & 20.9 & 18.7 & 6.1 & 4.1 \\
\hline & 8 & 81.3 & 73.6 & 72.6 & 20.9 & 27.3 & 6.1 & 0.1 \\
\hline
\end{tabular}

${ }^{\mathrm{a}} \mathrm{UV}$ light irradiation $(\lambda \max ; 254 \mathrm{~nm}, 0-8 \mathrm{~J}) .{ }^{\mathrm{b}}$ Water contact angles (deg) using contact angle meter (Excimer inc., SImage ). ${ }^{\mathrm{c}}$ XPS measurements were carried out on an XPS -APEX (Physical Electronics Co. Ltd.) with an $\mathrm{Al} \mathrm{K} \alpha \mathrm{X}$-ray source $(150 \mathrm{~W})$. Chamber pressure; $10^{-9}$ - $10^{-10} \mathrm{~Pa}$; take off angles; $45^{\circ}$.

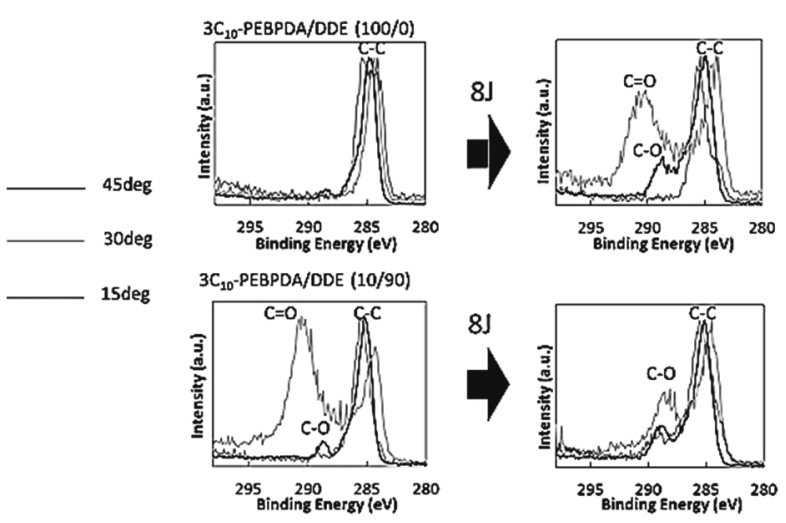

Fig. 6. XPS narrow scan of $\mathrm{C}_{1 \mathrm{~s}}$ of polyimides based on 3,4'-ODPA $/ 3 \mathrm{C}_{10}$-PEBPDA/DDE before and after UV light irradiation (Take-off angles; $45 \mathrm{deg}, 30 \mathrm{deg}, 15 \mathrm{deg}$ ).

It was observed that RMS (root mean square) values that indicated the micro roughness of film surface were slightly increased with the amounts of $3 \mathrm{C}_{10^{-}}$ PEBPDA segments before UV light irradiation, meaning that the existence of long-chain alkyl groups somewhat affect the surface roughness. After UV light irradiation, these micro roughness somewhat increased probably because of the film roughening by the UV light irradiation, and seem not to be correlated with the changes of surface wettability. Thus, it can be concluded that the changes of surface wettability of polyimide films are occurred mainly by the changes of chemical structures in polyimide surface.

\subsection{Elucidation of the mechanism of the wettability change}

Finally, the following experimental were carried out to elucidate the mechanism of the wettability change of polyimides by UV light irradiation. Firstly, UV light irradiation to the polyimide; 

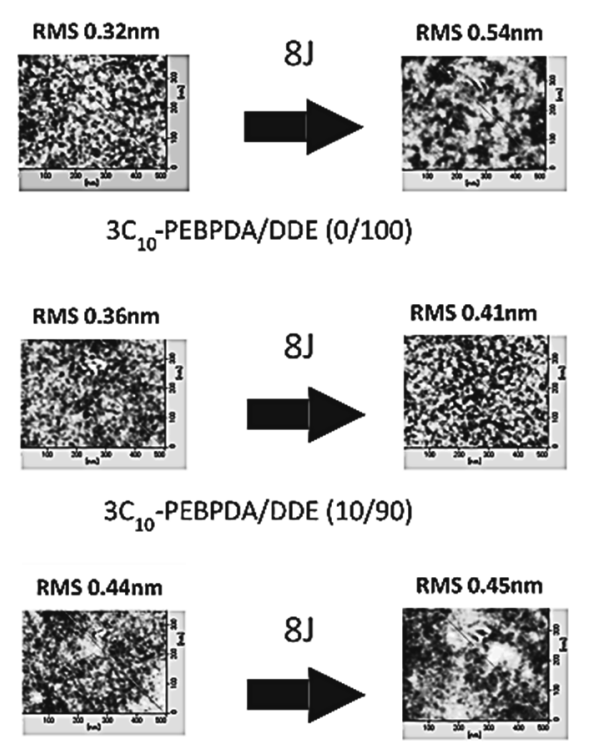

$3 C_{10}$-PEBPDA/DDE (50/50)

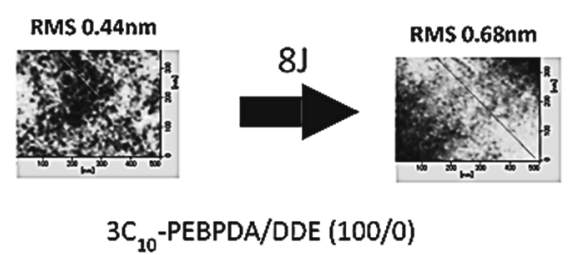

Fig. 7. AFM images of the polyimides based on 3,4'ODPA $/ 3 \mathrm{C}_{10}$-PEBPDA/DDE before and after UV light irradiation.

\section{3,4'-ODPA/3C 10 -PEBPDA $\quad(100 / 100)$ in} dichloromethane $(0.05 \mathrm{mmol}$ unit/L), that is $\mathrm{UV}$ transparent solution, was performed to analyze the photo-degradation products. After the UV light irradiation $(8 \mathrm{~J})$ to the polyimide solution in quartz cell, the solution was poured in a large amounts of methanol and ${ }^{1} \mathrm{H}$ NMR spectra of the precipitated polyimide (methanol insoluble parts) and the methanol soluble parts were measured and compared with ${ }^{1} \mathrm{H}$ NMR spectra of the original polyimide before UV light irradiation (Fig. 8). Consequently, the similar peaks appeared in ${ }^{1} \mathrm{H}$ NMR spectra of the original polyimide and the precipitated polyimide, while large aliphatic proton peaks and very small aromatic peaks appeared in ${ }^{1} \mathrm{H}$ NMR spectra of methanol soluble parts. Although photoreaction in the solution and photoreaction of the solid surface cannot be completely the same, it is confirmed that the scission of the long-chain alkyl groups occur in the photo-irradiation process.

Secondly, the effect of atmospheres in the course of UV irradiation were investigated using the quartz cell with the seal cap in which the oxygen or argon

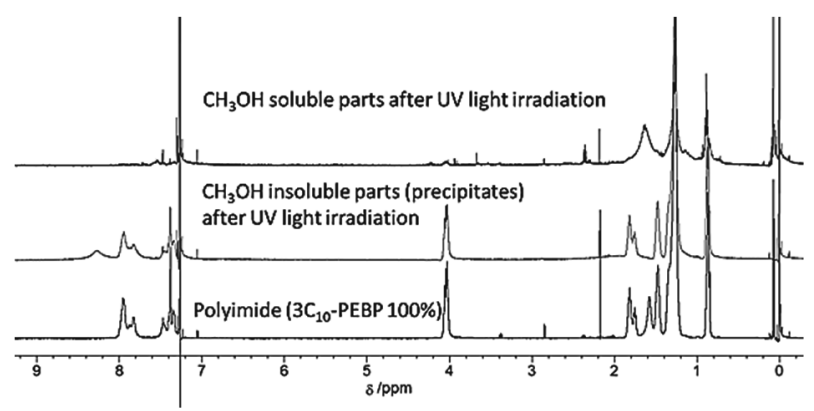

Fig. 8. ${ }^{1} \mathrm{H}$ NMR spectra in UV light irradiation experiment using polyimide solution (3,4'-ODPA/DDE homopolyimide in dichloromethane solution; $0.05 \mathrm{mmol}$ unit/L, UV light irradiation energy; $8 \mathrm{~J}$ ).

gas and polyimide film on glass substrates were enclosed (Fig. 9). In argon atmosphere, the water contact angle of the polyimide containing $10 \mathrm{~mol} \%$ of $3 \mathrm{C}_{10}$-PEBPDA slightly reduced from $95 \mathrm{deg}$ to $87 \mathrm{deg}$ by UV light irradiation, while those of the polyimide containing $100 \mathrm{~mol} \%$ of $3 \mathrm{C}_{10}$-PEBPDA are the quite same; $103 \mathrm{deg}$. In air or oxygen atmosphere, the water contact angle of the polyimide containing $10 \mathrm{~mol} \%$ of $3 \mathrm{C}_{10}$-PEBPDA largely decreased from $95 \mathrm{deg}$ to $50-55 \mathrm{deg}$ by UV

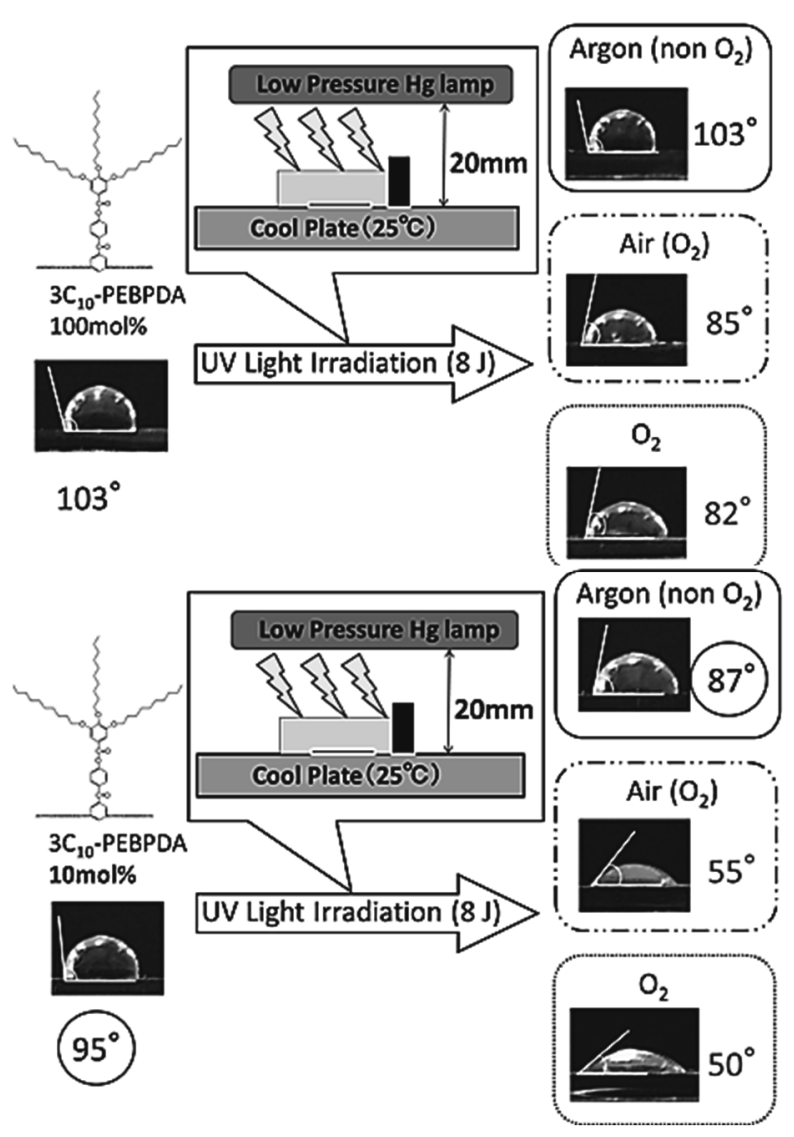

Fig. 9. Effect of atmospheres (argon, air, oxygen) on the course of UV light irradiation to the change of surface wettability. 
light irradiation, while those of the polyimide containing $\quad 100 \quad \mathrm{~mol} \%$ of $3 \mathrm{C}_{10}$-PEBPDA considerably decreased from 103 deg to $82-85 \mathrm{deg}$. From these results, it is convinced that the changes of surface wettability mainly occurs by the photooxidation and eventually hydroxyl groups and carboxyl groups generate on the polyimide surface. It is interesting that the margins of the decrease of contact angles after UV light irradiation in air or oxygen atmosphere are larger in the case of the polyimide containing $10 \mathrm{~mol} \%$ of $3 \mathrm{C}_{10}$-PEBPDA than in the case of the polyimide containing 100 $\mathrm{mol} \%$. It is again speculated that a large amounts of long-chain alkyl groups cover the polyimide surface even after UV light irradiation in the case of the polyimide containing $100 \mathrm{~mol} \%$.

\section{Conclusion}

The thin films of polyimides bearing three long-chain alkyl groups were irradiated by UV light, and the contact angles for the water decreased from near $100^{\circ}$ (hydrophobicity) to near $50^{\circ}$ (hydrophilicity) in proportion to irradiated UV light energy. From the result of surface analysis, it is recognized that the hydrophobic long-chain alkyl groups on the polyimide surface decrease and the hydrophilic groups generate on their surface mainly by the scission of long-chain alkyl groups and the photo oxidation. The changes of surface wettability by UV light irradiation were larger in the case of copolyimides containing smaller amounts of long-chain alkyl groups $\left(3 \mathrm{C}_{10}\right.$-PEBPDA; $25 \mathrm{~mol} \%, 10$ mol\%). It can be presumed that this phenomena is based on "the concentration effect" that the larger amounts of long-chain alkyl groups cover the top surface of polyimides even though the hydrophilic groups generate on their surface by UV light irradiation and XPS analysis supports this effect. Practically, the reduction of the amounts of special monomer, $3 \mathrm{C}_{10}$-PEBPDA is the great merit. Although these results contain the similar ones previously reported by our laboratory, the mechanism of the surface wettability changes is considerably clarified in this paper.

The fine-tuning of dimaine monomer structures, the addition of photo acid generator, the variation of hydrophobic groups, the reversible changes of surface wettability by UV light irradiation are now under investigation.

\section{Acknowledgements}

This work was supported by JSPS KAKENHI Grant Number 16K05924. This work was performed under the Cooperative Research Program of "Network Joint Research Center for Materials and Devices" (Dr. Atsushi Takahara of Kyushu University). Financial supports from RICOH Co., Ltd. is gratefully acknowledged. The authors thank Shanghai Research Institute of Synthetic Resins for providing 3,4'-ODPA.

\section{References}

1. "Polyimides", M.Ghosh and K.L.Miital, Eds., Dekker, New York (1996).

2. "Polyimides and Other High Temperature Polymers: Synthesis, Characterization and Applications", M.Ghosh, Ed., Vol. 5, Koninklike Brill NV, Leiden (2009).

3. C. Kim, M. Nogi, K. Suganuma, and Y. Yamamoto, ACS Appl. Mater. Interfaces, 4 (2012) 2168.

4. K. Suzuki, K. Yutani, M. Nakashima, A. Onodera, S. Mizukami, M. Kato, T. Tano, H. Tomono, M. Yanagisawa, and K. Kameyama, J. Imaging Soc. Jpn., 50 (2011) 142.

5. Y. Tsuda, Y. Hashimoto, and T. Matsuda, Kobunshi Ronbunshu (Japanese), 68 (2011) 24.

6. Y. Tsuda, J. Photopolym. Sci. Technol., 26 (2013) 345.

7. Y. Tsuda and Y. Kawashima, J. Photopolym. Sci. Technol. 27 (2014) 161.

8. Y. Tsuda and S. Kawabata, J. Photopolym. Sci. Technol., 27 (2014) 277.

9. Y. Tsuda, R. Nakamura, S. Osajima, and T. Matsuda, High Perform. Polym., 27 (2015) 46.

10. Y. Tsuda and R. Shiki, J. Photopolym. Sci. Technol., 28 (2015) 191.

11. Y. Tsuda, M. Tahira, N. Shinohara, and D. Sakata, J. Photopolym. Sci. Technol., 28 (2015) 191.

12. Y. Tsuda and D. Sakata, J. Photopolym. Sci. Technol., 29 (2016) 283.

13. Y. Tsuda and R. Shiki, J. Photopolym. Sci. Technol., 29 (2016) 265.

14. Y. Tsuda, J. Photopolym. Sci. Technol., 29 (2016) 383.

15. Y. Tsuda, Kobunshi Ronbunshu (Japanese), 74 (2017) 10.

16. J.-B. Baek and F. W. Harris, J. Polym. Sci. Part A: 
Polym. Chem., 41 (2003) 2374.

17. V. S. K. Balagurusamy, G. Ungar, V. Percec, and G. Johansson, J. Am. Chem. Soc., 119 (1997) 1539.

18. V. Percec, W. D. Cho, M. Moeller, S. A. Prokhorova, G. Ungar, and D. J. P. Yeardley, J. Am. Chem. Soc., 122 (2000) 4249.

19. Y. Tsuda, "Polyimides and Other High
Temperature Polymers: Synthesis, Characterization and Applications", M.Ghosh, Ed., Vol. 5, Koninklike Brill NV, Leiden (2009) 17.

20. Y. Tsuda, "Features of Liquid Crystal Display Materials and Processes", N. V. Kamania Ed., Intech, Croatia (2011) 3.

21. M. X. Ding, Prog. Polym. Sci., 32 (2007) 623. 